\title{
Utilization Conflict Analysis of Fisheries Resources with Tin Mining and Marine Tourism in East Coast of Bangka Island
}

\author{
Endang Bidayani ${ }^{1}$, Kurniawan $^{2}$, Leni Anggeraini ${ }^{3}$, Siti Aisyah ${ }^{4}$ \\ \{endangbidayani@gmail.com ${ }^{1}$ \} \\ Universitas Bangka Belitung, Indonesia ${ }^{1,2,3,4}$
}

\begin{abstract}
Conflict analysis uses a stakeholder analysis approach. The analysis aims to determine the potential and conflict management policies between stakeholders in the east coast region of Bangka Island. The method used in the form of classifying a number of issues related to coastal resource management, namely between fishermen, tin miners (unconventional mining) and marine tourism actors. Thus, providing an overview of the potential conflicts that occur in the region. The potential for conflict is then analyzed using one of the conflict analyses tools, namely onion analysis. Some matters relating to the management of the east coast resources of Bangka Island are classified based on issues in the field. There are at least four main issues that can be examined from the results of interviews, namely environmental issues, social issues, issues of low enforcement, and economic issues. The results of the analysis show that there is a similarity of needs that are the point of conflict, namely the utilization of coastal resources. Good conflict management for the long term in the process of resource management is through negotiation. Negotiations can take the form of deliberations to find collective agreements that can accommodate stakeholders. The agreement is related to the empowerment of community members, especially fishermen and tin miners (unconventional mining) in creating a harmonious life in the community.
\end{abstract}

Keywords: Conflict, Bangka, Utilization, Coastal Resources.

\section{Introduction}

Bangka Belitung Islands Province (Babel) is one of the largest tins producing regions in Indonesia with supplies reaching 70,000-80,000 tons per year. PT Timah, Tbk contributed $45 \%$ of tin metal production in Indonesia, with an export value of USD 5,000,000 [1].

In general, the economy in the province is still dependent on the mining sector. Most of this regional income is still supported by the income from tin production. It could even be said, infrastructure development in Babylon was contributed by this sector. Tin is the largest export, accounting for 83.37 percent of the total exports of the Bangka Belitung Islands Province. The main goal of tin exports in May 2015 was Singapore which reached US \$ 32.82 million or 49.04 percent of the total tin exports [2].

Tin mining activities in the sea, on the other hand have caused negative impacts on the environment, including reducing water quality, damaging coral reef ecosystems, and causing physical degradation of coastal habitats. As a result, tourism and fishing activities are disrupted [3]. 
In general, this research is expected to contribute to the preparation of WPP 711 management policies, namely through a comprehensive research mechanism involving experts from different disciplines. The purpose of this study in general is: to provide information on the impact of tin mining at sea and marine tourism activities on the utilization of fisheries resources, so that it will also have an impact on the achievement of fisheries targets WPP 711. Based on this information, managers of WPP 711 can develop strategies and policies that are more-right.

Specifically, overlapping of resource use on the east coast of Bangka Island between tin mining, capture fisheries and marine tourism, should be regulated so that each sector can obtain optimal benefit value. Specifically, this study aims to assist the Provincial Government of the Bangka Belitung Islands to determine priorities for sustainable capture fisheries management strategies on the east coast of Bangka Island.

\section{Research Method}

This research uses survey method. The sampling/respondent method used was a purposive sampling technique. This method is done by selecting samples/respondents based on certain characteristics that have been determined previously [4]. The population in this study is the community (owner fishermen who represent the characteristics of the whole fisherman who catches fish), tourism operators and tin miners (unconventional mining).

The total number of respondents in this study were 222 people consisting of 100 fishermen, 41 tin miners, and 81 tour operators. The research sites included Bangka Regency, namely Rebo Village, Takari Village, Air Antu Village and PPN Sungailiat. Whereas Central Bangka Regency covers Batu Belubang Village, Baskara Bhakti Village and Kurau Village. And the City of Pangkalpinang includes the Village of Pangkal Arang, Pasir Padi and Tanjung Bunga. Conflict analysis uses a stakeholder analysis approach. The potential for conflict is then analyzed using one of the conflict analyses tools, namely onion analysis.

\section{Result and Discussion}

Conflict analysis uses a stakeholder analysis approach. The analysis aims to find out the potential and conflict management policies between stakeholders in the north coast of Bangka Island. The method used in the form of classifying a number of issues related to coastal resource management, namely between fishermen, tin miners (unconventional mining) and marine tourism actors. Thus, providing an overview of the potential conflicts that occur in the region.

The potential for conflict is then analyzed using one of the conflict analyses tools, namely onion analysis. Some matters relating to the management of the east coast resources of Bangka Island are classified based on issues in the field. There are at least four main issues that can be examined from the results of interviews, namely environmental issues, social issues, issues of lawlessness (unconventional mining policing), and economic issues. 


\subsection{Environmental Issues}

Environmental issues of the impact of tin mining (unconventional mining) are analyzed part of district/city area. Based on the results of the analysis, the main problems of the aquatic environment of the impact of mining the main unconventional mining is the brightness of water and mud. As in Baskari Bhakti Village, Namang District, Batu Belubang Village, Pangkalan Baru District and Kurau Village, Koba District, Central Bangka Regency. Based on the Regional Environmental Status Report of the Province of Bangka Belitung (2016), Bangka Regency has a percentage of coral reef damage of 50 percent due to tin mining activities at sea, because the pores of coral reefs are covered by mining waste, which is mud, thus making coral reefs damaged.

The thickness of the mud in Batu Belubang Village from the coast towards the sea ranges from $30 \mathrm{~cm}-60 \mathrm{~cm}$. This condition makes it difficult for fishermen to go fishing. Fishermen must pay more to rent a barge of $6 \%$ of the catch. The barge's task is to bring the fish caught from the boat to the dock, and deliver the provisions of the fishermen when they go to sea. There are around 25 barges operating in the waters of Batu Belubang Village. The fishing gear of the majority of fishermen in Batu Belubang village are step on charts, floating charts, boat charts and fishing rods

The village of Baskari Bhakti also has a problem of low water brightness, and mud whose thickness reaches $30 \mathrm{~cm}$. In this village there is a division of village waters for fishing by fishermen and tin mining activities by miners, namely waters in Tanah Merah village for fishing activities, and Bedeng village waters for mining activities. The boundary area is marked by wooden stakes towards the sea along one kilometer. The fishing gear of the majority of fishermen in the village of Baskari Bhakti include small trawlers, nets, and fishing lines.

The problem in the village of Kurau is the same as the two previous villages, namely the brightness of the water and mud which causes silting of the estuary. So that fishing boats cannot go in and out of the pier at any time, because they are waiting for the tide.

Likewise, marine mining activities can cause sedimentation so that fish habitat is getting further into the open sea, and causing fishermen even farther away to catch fish. The results of field data collection on the respondents of tourism operators, tin miners and fishermen in the City of Pangkalpinang and Bangka Regency, shows the perception that the condition of the waters has begun to be polluted. Most of it is caused by the impact of illegal tin mining at sea. Thus, affecting the fishing for fishermen and damage the beauty of the beach for tourism businesses.

The mining sector is very influential on the tourism sector and the fisheries sector on the coast. Tin mining activities produce waste which is directly discharged into the waters after the washing stage. According to Anggoro [5], the continuous influx of waste into coastal waters can cause negative effects. The influx of waste in the coastal area will continuously experience concentration and accumulation in the aquatic ecosystem. This process occurs if heavy metals that enter the waters are not spread by turbulence and ocean currents. Parts of pollutants that are not diluted and distributed or carried to the high seas will be absorbed or concentrated through a biophysical-chemical process. Then the heavy metal is suspended in seawater (floating sediments) and accumulates to bottom sediments (dispersed).

The tourism sector and also the fisheries sector are important aspects, namely water quality in these waters, one of which is the brightness of the waters. The main factor causing the turbidity is the dredging of the waters caused by mining activities. Water brightness really determines what kind of biota is in it. In coral reef ecosystems need clean sea water. So that 
mining activities in liquid waste are already above the environmental quality standard, so that it becomes a pollutant. This will affect the activities of fishermen to look for fish and also tourists who see the beauty of coastal nature tourism.

Prianto and Husnah [6] explained that high sedimentation in coastal areas has caused changes in coastal landscape. This is due to the presence of tin mining along the coast of Bangka Island. The high level of mining activities along the coast has caused deepening in some parts due to the taking of seabed soils and in other parts piling up of soil grains.

Sedimentation of water bottom by sediments can damage and destroy benthic animal communities and other aquatic biota spawning sites. Suspended soil particles will cover the habitat (aquatic plants, soil surface) and eggs of all aquatic biota, so the eggs cannot develop properly. This impact will eventually lead to mass population declines which in the long run can reduce aquatic biodiversity.

Tin mining activities in coastal areas leave waste containing pollutants directly discharged into the waters without filtering in advance so as to directly or indirectly put significant pressure on the declining quality of aquatic ecosystems including coastal ecosystems that can affect spawning, feeding, fishing ground fish resources and another marine biota.

The direct impact is the change in the brightness of the waters, which in turn affects the fertility of the waters. In addition, the indirect impact is the farther fishing ground, the reduction in fish catches of fishermen of their type and size and the changing of the fishing profession into a supporter of the mining sector. In the City of Pangkalpinang, many fishermen rent their boats to miners to unconventional mine pontoons and receive motorbike maintenance services with a day care fee of IDR 5,000 per motor every night.

Seeing the above phenomenon, it is necessary to have a management policy directive regarding the effect of tin mining on the socio-economic conditions of the community in the coastal area of Bangka Island, which is the center of tin mining activities in Indonesia. By relying on the principle of environmental sustainability and it is hoped that the potential of fish resources can be utilized optimally to improve the welfare of fishermen on Bangka Island, Bangka Belitung Islands Province.

\subsection{Social Issues}

Analysis of social problems that arise as a result of tin mining (unconventional mining) for fishermen in Central Bangka Regency includes children's education, fisherman health and employment opportunities. The social issues that occurred in the conflict over the utilization of coastal resources in this study were obtained by two main sources that played a role, namely tin miners in the sea and capture fisheries.

Educational problems, as many as $73 \%$ of coastal children in Central Bangka Regency do not continue their education due to economic problems. The children of fishermen do not go to school (high school/equivalent) or college, because of the uncertain income caused by the season, and the high costs of catching fish. Fishermen have to catch fish as far as 30 miles, because the waters around the coast are many tin mining activities (less than 2 miles). Documentation of unconventional mining pontoons with a background of tin mining activities along Batu Belubang beach is presented in Figure 1. 


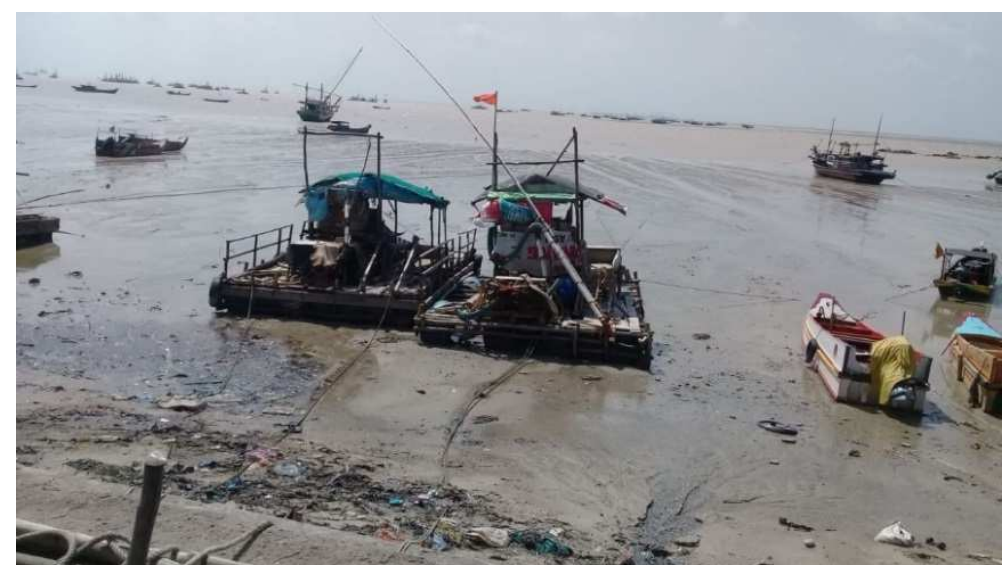

Fig. 1. Unconventional mining pontoons is being parked, with the background of unconventional mining activities on the coast of Batu Belubang Village, Pangkalan Baru District, Central Bangka Regency (Personal documentation, 2019)

Health problems, as many as $59 \%$ of fishermen have JKN / BPJS health insurance. The rest of the fishermen still use their own costs for treatment. Based on interviews, fishermen are still reluctant to take insurance because not all BPJS are free. But some have to pay themselves in the form of monthly fees. And that is considered burdensome for fishermen.

Regarding employment opportunities, $54 \%$ of fishermen stated that the quality of the waters in their area had an impact on fishing. Fishermen make fishing efforts in waters where there is no mining activity, and the area is outside the waters of their village. So, the mileage is further away. In addition, a number of fishermen in Batu Belubang Village also switched professions to become barge boosters, due to the relatively higher fishing costs. While revenue as a barge booster is $6 \%$ of the total catch of fishermen who use his services. So, it feels more promising. Barge transportation as presented in Figure 2.

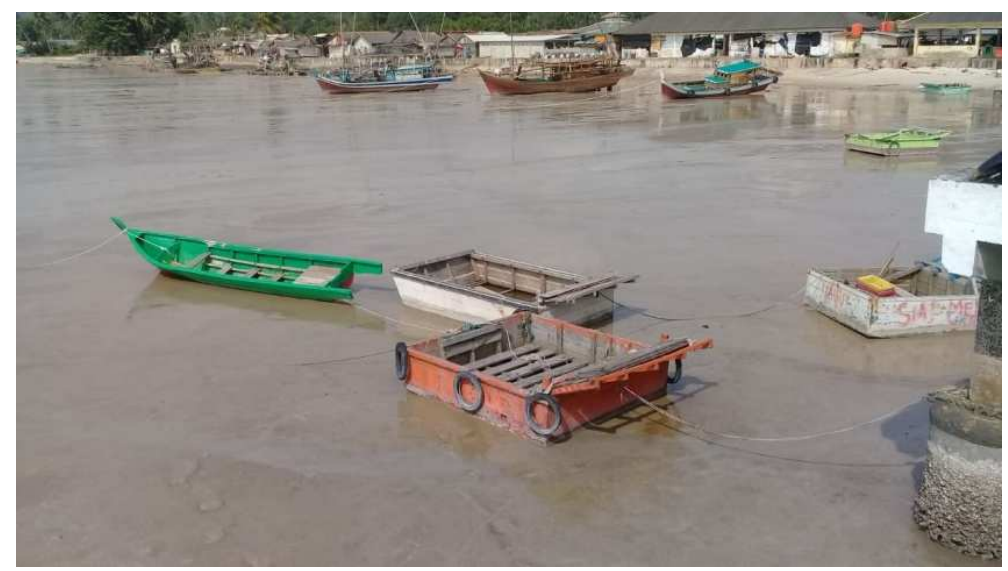

Fig. 2. Barge transportation (Personal documentation, 2019).

The results of field research by collecting data on respondents of fishermen and tin miners in the waters of the City of Pangkalpinang there are quite prominent social issues. One 
example is the case that occurred in Sinar Bulan Subdistrict, Pangkalpinang City. The Chairman of the Fishermen Group at that location also acts as an illegal tin miner and utilizes his fishing profession to obtain subsidized diesel fuel prices for mining purposes. This makes other fishermen who work as fishermen feel that this is not fair. This incident caused fishermen and tin miners in the village to intersect.

The problem of tin mining on Bangka Island is now the phenomenon of the iceberg which could one day explode and become a social problem that led to conflict with other communities. Both in the struggle for the utilization of coastal resources as well as the case that occurred in the village of Sinar Bulan.

\subsection{Issues of Violation of the Law (Unconventional Mining Control)}

Law enforcement by law enforcement is an effort by the local government to reduce existing social and environmental impacts, in addition to IT violating regulations. For miners who are caught, they will be punished according to the applicable legal regulations, including the seizure of the TI pontonier's seizure.

Quoted from Antara News [7], Pangkalpinang City Government disciplines and burns illegal tin ore mines that operate in the Rangkui River channel, for violating rules and unsettling the Pangkal Pinang City community. Controlling illegal mining, the City Government of Pangkalpinang cooperates with the TNI and Polri to eradicate illegal tin ore mining that is disturbing the community, damaging the environment and increasing the potential for natural disasters in the Pangkalpinang area.

The City Government of Pangkalpinang in its efforts to curb illegal mining in Pangkalpinang leads directly in every order to anticipate that there will be no more leaks when inspecting and controlling. This was also done as a confirmation of the regulation that in the Pangkalpinang area there was no mining. The results were not known that the miners in Pangkalpinang were not local residents but most residents who came from outside Pangkalpinang [8].

According to Murty and Yuningsih [9], illegal tin mining has become more widespread since the issuance of the Minister of Industry and Trade Decree number 144/MPP/Kep/4/1999 dated April 22, 1999 that Tin is categorized as free goods (not monitored) and revocation of tin status as a strategic commodity, so that it is no longer monopolized by one SOE and can be exported freely by anyone. With the Decree of the Minister of Industry and Trade, of course it causes rampant illegal tin mining activities, so it is felt that the Government needs to create a number of laws and regulations in an effort to anticipate violations and criminal acts in mining, tin mining in particular. Regulations that have been made by the Provincial Government of Bangka Belitung Islands in in order to tackle this illegal tin mining is Regional Regulation Number 7 of 2014 concerning Management of Mineral Mining. The Central Government has also issued a law governing this Tin Mining, which is regulated in Law Number 4 of 2009 concerning Mineral and Coal Mining

In the context of enforcing criminal law in overcoming the illegal tin mining crime, in this case the police conduct raids and control in their respective jurisdictions. In this case the Police conduct raids and control of illegal tin mining, this raid was carried out with the local Regional Government and Sat Pol PP and confiscated the operational equipment of the mining activities to be used as evidence.

Follow-up to the raid, the police conducted an investigation and investigation into the suspects of illegal tin mining perpetrators. After an investigation and investigation, the completed case file (P21) is forwarded to the prosecution and trial process. In the prosecution 
process the case file was submitted to the Pangkalpinang District Attorney's Office, and in the trial process it was conducted at the Pangkalpinang District Court.

Apart from conducting raids and policing which is carried out periodically by the Polres, in this case the Bangka Belitung Regional Police make several law enforcement efforts in other forms, namely:

a) Law enforcement is carried out through regular routine activities and PETI operations, both by the Regional Police and the Police.

b) Suppress the use of heavy equipment for illegal mining actors, targeting heavy equipment users (tenants and owners).

c) Pressing the distribution channels of the collectors, targeting sub-collectors, collectors, storage warehouses and houses / ponds which are used as storage facilities.

d) Suppressing illegal fuel distribution lines used for mining facilities, targeting containers, gas stations, transportation equipment and storage warehouses.

e) Pressing smuggling routes, targeting smugglers, transport equipment used, smuggling locations and discovering new modes of smuggling

\subsection{Economic Issues}

The disparity in income between fishermen and tour operators and tin miners, is undeniable, the main reason people still rely on tin as an economic support for the people of the Bangka Belitung Islands Province. The results of research on the east coast of Bangka Island show, the miner's per month income reached of IDR 80,432,927, tourism actors IDR $14,686,914$, and capture fisheries amounting to IDR 5,439,444.

The vast difference in income between fishermen, miners and tour operators makes it difficult for tin mining activities to be abandoned by the community, and has the potential to make other communities switch professions to become miners. This happened at the Pangkalpinang City research location in the Tanjung Bunga and Sinar Bulan area where fishermen we made respondents had a side job as illegal tin miners. Whereas for large-scale tourism actors who have been concerned in the field of tourism from the beginning so that it does not make economic issues in the use of coastal resources. Good conflict management for the long term in the process of resource management is through negotiation. Negotiations can take the form of deliberations to find collective agreements that can accommodate stakeholders. Local government can involve the community in developing coastal resource management policies.

\section{Conclusion}

The results of the analysis show that there is a similarity of needs that are the point of conflict, namely the utilization of coastal resources. Good conflict management for the long term in the process of resource management is through negotiation. Negotiations can take the form of deliberations to find collective agreements that can accommodate stakeholders. Local governments can involve the community in developing coastal resource management policies. The agreement is related to the empowerment of community members, especially fishermen and tin miners (TI) in creating a harmonious life in the community. 


\subsection{Acknowledgements}

a) The Margaret A. Cargill Foundation funded this work. Thank you to Collette Wabnitz, Mike Slinger, Todd Stevenson, Tony Nahacky, Andrew Rhyne, Hiro Ueda, andNick Connor. Special thanks to Linwood Pendleton, for providing advice on methodology and analysis.

b) CSF Indonesia.

c) FPIK IPB.

\section{References}

[1] PT Timah, "Pembaruan Ekspor Timah," 2018.

[2] B. P. Statistik, "Provinsi Kepulauan Bangka Belitung Dalam Angka 2017." Jakarta: BPS, 2018.

[3] E. Bidayani, Ekonomi sumberdaya pesisir yang tercemar. Universitas Brawijaya Press, 2014.

[4] M. Nazir, "Research methods," Jakarta Ghalia Indones., 1988.

[5] Anggoro, "Management of Coastal and Marine Resource," http://repository.utu.ac.id, 2001.

[6] E. . H. Prianto, "Unconventional Tin Mining: Its Impact on Damage to Public Aquatic Biodiversity on Bangka Island," Bawal J., vol. 2, no. 5, pp. 193-198, 2009.

[7] Antara News, "Pangkalpinang City Government Burns Illegal Mining," 2019. .

[8] Kumparan.com, "Mayor of Pangkalpinang Regulates Illegal Mining," 2019. [Online]. Available: http://www.kumparan.com. [Accessed: 11-Jul-2019].

[9] Murty; Yuningsih, "Efforts to Enforce Criminal Laws Against Criminal Acts of Illegal Tin Mining in Bangka Belitung Province," Simbur Cahaya J., vol. 24, no. 1, pp. 4348-4374, 2017. 